\title{
"MISSING ME ONE PLACE SEARCH ANOTHER": THREE PREVIOUSLY UNPUBLISHED WALT WHITMAN NOTEBOOKS
}

\author{
Charles B. Green
}

But to my jottings, taking them as they come, from the heap, without particular selection. There is little consecutiveness in dates. They run any time within nearly five or six years. Each was carelessly pencilled in the open air, at the time and place. The printers will learn this to some vexation perhaps, as much of their copy is from those hastilywritten first notes.

-Whitman, Specimen Days

Nowhere, perhaps, is Whitman's statement regarding his notetaking more applicable than when it comes to sorting through his daybooks and notebooks. The problem of establishing an accurate rendering of these scattered "jottings" can indeed lead to "some vexation," as discovered by Edward Grier and William White, the editors who undertook the daunting task of collecting and presenting this "heap" so as to dovetail into the even larger "heap" entitled The Collected Writings of Walt Whitman. These two editors have undeniably contributed much that is valuable to the Collected Writings, an overall project described by Gay Wilson Allen as "a monument to academic courage, faith, generosity, and scholarly work." The recent discovery of three unpublished Whitman notebooks in the Library of Congress's Charles E. Feinberg Collection of the Papers of Walt Whitman, however, has refocused attention upon Grier's and White's handling of their material and its rendering in the Collected Writings.

The original intention was to have the materials co-edited by the two scholars as a single collection encompassing all of Whitman's notebooks and prose manuscripts left incomplete or unpublished, but the editors soon parted ways, dividing the work into rough manuscript concentrations. Unfortunately, the consequence of this split was the production of two quite distinct works, Grier's six-volume Notebooks and Unpublished Prose Manuscripts (NUPM) and White's three-volume Daybooks and Notebooks, 1876-1891 (DBN). Meticulously edited at the level of detail, these volumes nonetheless suffer from a lack of unified organization. First, the absence of a comprehensive index requires readers to move back and forth between the works, creating their own system of cross-referencing. Second, especially in the case of White's work, gaps 
appear in the materials. As Ed Folsom notes in "The Whitman Project: A Review Essay," "there is an uncomfortable sense that these volumes are a sort of hodge-podge of things that White . . . happened to have access to, and that happened to be ready to print . . . even if they didn't quite fit together." 2 Third, neither editor makes it precisely clear what has been left out, with White brushing aside potential criticisms of such omissions with the rationale that "sooner or later one must stop searching and researching, and go to print." 3

When Grier and White divided up their overall project, it was decided that White would edit the daybook and notebook manuscripts located in Charles Feinberg's extensive collection, while Grier would attempt to tackle everything else. For reasons not made clear, White limited his focus primarily to materials dating from 1876 to 1891 and promptly published three volumes in $1978 .{ }^{4}$ Grier labored for a more extended period, drawing together six volumes, and was preparing to deliver his work to press when it occurred to him that White, in ignoring materials dating prior to 1876, had omitted manuscripts of significant importance. ${ }^{5}$ Crossing the agreed-upon boundaries, Grier decided to add approximately forty manuscripts located within the Feinberg-Whitman Collection to his own volumes. During this unorthodox editorial process some materials inevitably fell through the cracks. The recent discovery of three unpublished notebooks located within the FeinbergWhitman Collection provides just such an example and demonstrates some of the problems inherent in this fractured project.

The first three items in Container One of the Feinberg-Whitman Collection are a homemade manuscript notebook dated "September \& October 1863," a folder labeled "Address Books, 1876-86," and a folder labeled "April-May 1879, Notebooks and Address Books." The first and third items are transcribed in NUPM and DBN respectively. The problem occurs when we turn to the contents of the folder situated between these items. This folder, labeled "Address Books 1876-86," contains three small notebooks which appear neither in Grier's nor in White's gatherings. While the date on the folder falls within the parameters of White's focus, these materials could also have come under the scrutiny of Grier's eleventh-hour assessment. Possibly, both editors reviewed these materials only to dismiss them as mundane and unimportant. Grier's introduction specifically speaks of his decision to omit certain "classes" of manuscripts from his assemblage and, though White does not formally make such a declaration, the fact that he chose to slight so much of the Feinberg-Whitman Collection indicates a de facto exclusion process. ${ }^{6}$ Yet, these notebooks contain information that seems just as important as other material the editors did choose to include. In these pages, Whitman jots down trial lines and titles for his poetry and prose, records ideas for his Lincoln lecture, composes a catalog of spring blos- 
soms, and makes notes about his friends, his health, and his daily activities.

What makes the omission of these notebooks even more curious is that White, who in his introduction initially appears to express concern over this issue of what to include and what to leave out, worrying whether these rawest of Whitman documentary forms deserve a place in a collection of the poet's writings at all, ultimately concludes that all Whitman materials do have reference value. ${ }^{7}$ In his review essay, Ed Folsom agrees with this conclusion and suggests that White's annotations, when taken as a whole along with Whitman's "jots and doodles," offer a useful "kind of do-it-yourself biography of Whitman's later years." Just as the notebooks collected within NUPM have helped to illuminate Whitman's transition from political journalist of the 1840 s to poetprophet of the $1850 \mathrm{~s}$ and $1860 \mathrm{~s}$, and materials brought together within the $D B N$ have served to shed light on the marked shift that occurred in Whitman's poetics during the 1870s, these records may prove to be of significance. ${ }^{9}$ Materials that appear meaningless to scholars working with one set of assumptions can contain, for later scholars, vitally important clues. Each item left behind is another puzzle piece that can be used in various ways as people construct and reconstruct new versions of Whitman's life and work. Perhaps the poet said it best himself in his prophetic advice at the end of "Song of Myself": "Missing me one place search another. ..." At the very least, these unpublished "leaves" add to or corroborate things already known or suspected, and their absence from the Collected Writings calls into question the handling of the Feinberg-Whitman Collection, suggesting that Edward Grier may have been premature in pronouncing the project "complete."

\section{College of William E Mary}

Glendale $^{11}$

birthdays

Harry Stafford ${ }^{12}$

23 March

Mrs. $\mathrm{S}^{13}$

4th April

window shades

406 Arch St

Ristine

Gold \& Silver Plater
[Glendale Notebook ${ }^{10}$ ]

[leaf 1: all but approx. $1.3 \mathrm{~cm}$ at top has been removed (cut out)]

[leaves 2-6: removed (cut out)] [leaf 7]

[These 8 lines entered with purple pencil] 
of Watches, Jewelry, \&c 806 Race

Straw hats done up 203 Race

Allen Leslie Belleville ${ }^{14}$

put in Indians ${ }^{15}$

Navajo

Apache

Pueblo

glasses

at Cooper's Sept '8

No 11 [leaves 8-9: all but $.85-1.3 \mathrm{~cm}$ of leaf removed (cut out), blank]

[leaf 10: lower half of leaf removed (torn out)]

[leaf 11: all but $1.9 \mathrm{~cm}$ of leaf removed (torn out), blank]

[leaf 12: all but $7.62 \mathrm{~cm}$ of leaf removed (torn out)]

[leaves 13-15: all but $.64 \mathrm{~cm}$ removed (cut out), blank]

[leaf 16]

[These 9 lines entered with purple pencil]

Box 267

[leaf 17: all but $.64-1.3 \mathrm{~cm}$ removed (cut out), blank]

[leaf 18: all but $1.3-2.54 \mathrm{~cm}$ removed (torn out), blank]

[leaf 19]

Mm: Hutchison, Burlington, N.J. [This address and names are not in Whitman's

€.C Curtis Clay Hutchison hand]

George Hutchison. ${ }^{17}$

John B. Williams ${ }^{18}$

$24 \mathrm{~W} 14^{\text {th }}$

N Y City-

[These three lines entered with purple pencil]

[leaves 20-21: full leaf, blank]

[leaf 22: all but $.64-1.3 \mathrm{~cm}$ removed (cut out), blank]

[leaf 23: all but $.64 \mathrm{~cm}$ removed (cut out), blank]

[leaves 24-31: full leaf, blank]

[leaf 32: text entered vertically]

- Ring town ${ }^{19}$

[These 9 lines entered vertically, with purple pencil]

Reading road

get ticket for Ring town

Tuesday, Thursday \& Saturday

Louis Wagner ${ }^{20}$

depot

train leaves 945 a.m.

gets there at $2: 35$

[leaf 33: full leaf, blank]

[leaf 34: all but $.64 \mathrm{~cm}$ removed (torn out), blank] 
[leaf 35: all but $7.62 \mathrm{~cm}$ removed (torn out), blank]

[leaves 36-37: all but .32-.64cm removed (cut out), blank]

[leaf 38]

$7 \quad 400$

$7 \longdiv { \frac { 1 6 0 0 } { 2 0 } }$

228

$7 / \underline{400}$

57.143

$\lcm{444}$

[leaf 38: reverse]

Henry Whitall Phillipsburg N.J. ${ }^{21}$ [Not in Whitman's hand]

[leaf 39: blank]

[leaf 39: reverse]

early in May

cherry blossoms

pear

almond "

- earlywild violets

middle of May

apple blossoms the cedar

dog-wood the pretty

wild-honey suckle little clusters

latter middle of May. of pine-seeds

white black blackberry blossoms

stra wild strawberry

low in the ground in the woods

- profusion of little white or yellow

wild flowers. ${ }^{22}$

Joshua Killingbeck ${ }^{23}$

449 Benson

[leaf 40: all but $.64 \mathrm{~cm}$ removed (cut out), blank]

Mrs Gilchrist ${ }^{25}$

[Mrs. Gilchrist Notebook $\left.{ }^{24}\right]$

[leaf 1: all but $.32 \mathrm{~cm}$ removed (cut out), blank]

[leaf 2: all but $7.62 \mathrm{~cm}$ removed (cut out)]

\section{Somerset St Boston}

In the summer, in the rush of excursions, the streets \& spaces 
Never did the place

look

Two Rivulets

[leaf 2: reverse]

of + Songs

Sequeling Leaves of Grass ${ }^{26}$

Letter from Walt Whitman

[leaves 3-8: all but between .32 and $.64 \mathrm{~cm}$ removed (cut-out), blank]

[leaf 9: all but $10.16 \mathrm{~cm}$ removed (cut out)]

Gossip \& Going around

A run across Central Jersey ${ }^{27}$

Rubber goods

Tillinghast

12 So $2 \mathrm{~d}$ St Phila

[leaf 10: all but $1.3 \mathrm{~cm}$ removed (cut out), blank]

Arch Street

Perfumery - 510

[leaf 11: all but $10.16 \mathrm{~cm}$ removed (cut out), blank]

[These 7 lines entered in black ink]

Photo Materials

\& frames 624

Buttons - 804

Globes \& School

furniture

above 12 th

[leaf 12: lines entered vertically]

I'd
I'll make the Songs of the Nation- who let make pass
- the Laws or lead to War moy
Old Proverb
[revisions entered in blue pencil]

I'll make the Songs of The States

I'd make the songs of the Nation -who'er may -who make the laws or lead to war they may

Milliard Shute ${ }^{28}$

[leaf 13: all but $.32 \mathrm{~cm}$ removed (cut out), blank] [leaf 14: all but $1.9 \mathrm{~cm}$ removed (cut out)]

Please call at 431 Stevens St. ${ }^{29}$ $\&$ get shoes to

[leaf 15: all but $.32 \mathrm{~cm}$ removed (cut out), blank] [leaf 16: full leaf, blank]

[leaf 16: reverse, text entered vertically]

[leaves 17-18: all but $1.3 \mathrm{~cm}$ removed (cut out), blank]

[leaf 19: full leaf, blank]

[leaf 20: all but $.32 \mathrm{~cm}$ removed (cut out), blank]

[leaves 21-22: full leaf, blank]

[leaf 23: all but $8.82 \mathrm{~cm}$ removed (cut out)]

P.H. Poten ${ }^{30}$

Wyoming

[Not in Whitman's hand]

Luzerne Co. Pa. 
Dr. Thomas ${ }^{31}$

1807 Chestnut

St

only

What is composed out

what is set up out of

them that is - is it not ?-

of main importanee

that is important.

Death of Lincoln

finish \& condense the

preparatory description

of the condition, scenes, \&c.

before the war

make it more graphic,

clear - make it brief. ${ }^{32}$ [leaf 24: full leaf, blank]

[leaf 24: reverse]

[leaf 25: full leaf, blank]

[leaf 26: all but .32cm removed (cut out), blank]

[leaf 27: all but $10.16 \mathrm{~cm}$ removed (cut out)] [leaf 28: full leaf, blank]

[leaf 28: reverse]

\section{Gertainly of course}

It is quite eertain my

friends that I shall not

be able to tell you any

truly new at least in the way of

thing but just what or events you may know

before - at any rate rate

faets orevents. But

our history, or the whole world

these facts or events, history

is a favorable notion of

what only the more than

mine are as $\wedge$ the font of

types, the letters in their

boxes in the case ? it

[page torn through "the case"]

[leaves 29-30: all but $3.18 \mathrm{~cm}$ removed (cut out),

blank]

Two Rivulets

[leaf 30: reverse]

of Songs ${ }^{33}$

addenda to LEAvES of Grass

[leaves 31-40: all but between .32 and $.64 \mathrm{~cm}$

removed (cut out), blank] 
Dec 11, '77 - car 111 - John

[Dec 11, '77 Notebook ${ }^{34}$ ]

[inside front cover blank]

[flyleaf: all but $.64-1.3 \mathrm{~cm}$ removed (torn out), blank]

[leaf $1: 3.84 \mathrm{~cm}$ cut-out removed from bottom of leaf]

Nutter, dyspepsia. English

stock, (father an opera-

singer) born in Richmond

- been a foot-runner - horse

fancier-married - been driving

'6 mos $={ }^{35}$

[tipped-in address from newspaper advertisement:

image of eyeglasses followed by two printed lines:

H. Cutler Practical Optician,

310 S. $5^{\text {th }}$ st. Established $1819^{36}$ ]

D.Y. Kilgore 394 + Powel[ton?]

Ave West Phil ${ }^{\mathbf{3} 7}$

Baring St. Car on Market

Office 605 Walnut

Ivan C. Michels. ${ }^{38}$

[not in Whitman's hand]

[E]lla Wright ${ }^{39}$

Herby's picture at ${ }^{40}$

Payne's - 624 Arch $^{41}$

[leaves 2-3: all but .64cm removed (cut out), blank]

get "Manual for Nursing" [leaf 4]

12 mo. 143 pp. G P Putnam's Sons

atso "Cerebral Hyperaemia"

New York

by Dr Wm H Hammond

12 mo. 108 pp. G P. Putnam's Sons

N Y

Nota - Bene's (name for a book)

Chas A Layer ${ }^{42} \quad$ [name not in Whitman's hand]

conductor Camden \&

Atlantic RR

March 2 '78

Maggie Smithers ${ }^{43}$

N.E. C. or $4^{\text {th }}$ and Wash.

[name and address not in Whitman's hand]

Elwood L. ${ }^{\mathrm{L}}$ Griscom $^{44}$

(Broadway coach - Camden

[leaf 5: $7.62 \mathrm{~cm}$ cutout removed near top of leaf]

[name not in Whitman's hand]

$$
\text { March '78) }
$$


Louis J. Wagner (RR news agent) [these three lines not in Whitman's hand] No. 421 Taylor Ave

Camden N. J. ${ }^{45}$
Augustus E. A. Johnston ${ }^{46}$
[not in Whitman's hand]
George W. Dowles ${ }^{47}$
(Conductor 120 Car - Union
[leaf 6: $8.92 \mathrm{~cm}$ torn out near top of leaf, blank] March '78 Phil.)

\section{James Huneker ${ }^{48}$ \\ 1711 Race St. -

\begin{abstract}
Abraham Lincoln
that the practical

mechanic's farm

(see printed slip)
\end{abstract}

(young man that came to see me abt April 18

in Camden)
Wm M. F. Round ${ }^{49}$
"Rosecroft"
Still River -
Worcester Co -
Mass -

Patrick A Connelly. ${ }^{50}$

hat bands Horsman's

$5^{\text {th }} \&$ cherry

\section{Charlotte Pendleton ${ }^{51}$ \\ Cincinnati \\ Ohio.}

Craig E. Lippincott ${ }^{52}$

715 Market St

Philadelphia

$\mathrm{Pa}$.

[leaf 12]

\section{[leaf 7]}

[printed slip missing]

[leaf 8: $5 \mathrm{~cm}$ cutout removed near top of leaf, blank]

[leaf 9]

[leaf 10: leaf removed (cut out)]

[leaf $11: 3.84 \mathrm{~cm}$ cutout removed near top of leaf, blank]

[name not in Whitman's hand]

[these four lines not in Whitman's hand] 
Mrs Gilchrist ${ }^{53}$

Round House Hotel

Northampton

Mass.

Chas F. Bender ${ }^{54}$

562 Berkley St

Camden, N. J.

So $4^{\text {th }}-$ Phil.

perfumery $20{ }^{2} 26$

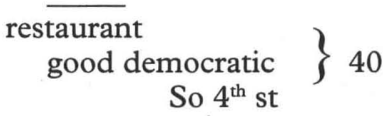

Mrs John Bigelow ${ }^{55}$

Highland Falls

Orange Co.

New York

them. Their hum

Erastus Brainerd ${ }^{56}$

Mrs Sarah Knight ${ }^{57}$

Glen Elg. po

Howard Co

Maryland

Palm soap

Koone Van Hooge \& Co

Phila. [these three lines not in Whitman's hand]

[these three lines not in Whitman's hand]

[leaves 13-16: removed (torn out)]

[leaf 17]

[four lines not in Whitman's hand]

[leaves 18-21: removed (cut out)]

[leaf 22: several cut-outs, $5 \mathrm{~cm}$ remaining intact at bottom of leaf, blank]

[leaf 23: removed (torn out)]

[leaves 24-47: removed (cut out)]

[leaf 48]

[leaves 49-59: removed (cut out)]

[leaf $60: 12.7 \mathrm{~cm}$ cutout removed from top of leaf, blank]

[leaves 61-62: removed (cut out)]

[leaf 63: $8.26 \mathrm{~cm}$ cutout removed from top of leaf, blank]

[leaf 64: removed (cutout)]

[leaf 65: $11.5 \mathrm{~cm}$ cutout removed at top of leaf, blank]

[rear flyleaf: written vertically]

[rear flyleaf: reverse] 


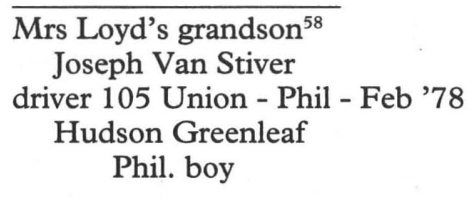

[inside rear cover: blank]

\section{NOTES}

1. "Editing the Writings of Walt Whitman: A million dollar project without a million dollars," Arts and Sciences 1 (Fall 1962/1963), 7-12. The epigraph at the beginning of my essay is from Prose Works 1892, edited by Floyd Stovall (New York: New York University Press, 1963-1964), 1:122; hereafter abbreviated $P W$.

2. Philological Quarterly 61 (1982), 375.

3. Daybooks and Notebooks, edited by William White (New York: New York University Press, 1978), 1:viii. Hereafter abbreviated $D B N$.

4. White's rationale behind this decision is left unclear. In his "Introduction" to the $D B N$ he simply states that the materials that he chose to include "belong in an edition of Whitman's collected works if such productions are to achieve anything approaching completeness." His rendering of the Daybooks are meant, he suggests, to "give us the bare bones of the poet's outward life" as they supplement the biographical information in Whitman's Correspondence, Horace Traubel's With Walt Whitman in Camden, and Specimen Days. The inclusion of the Canadian diary, the other journals and notes, Words, and The Primer of Words, he adds, are intended to "fill out the record" (1:xviiixix).

5. In his introduction, Grier notes that "publication of the Feinberg Manuscripts was limited to only a selection, Daybooks and Notebooks, ed. William White. Since some forty of the manuscripts left unpublished, especially those before 1865, are of striking importance, I have taken them on at the last minute as my responsibility" (Notebooks and Unpublished Prose Manuscripts, edited by Edward F. Grier [New York: New York University Press, 1984], 1:xvi; hereafter abbreviated NUPM).

6. NUPM 1:xvi.

7. $D B N$ 1:vi-vii.

8. Philological Quarterly, 373.

9. Betsy Erkkila makes a similar point regarding the value of this type of material in her review of the NUPM, suggesting that "items that appear to be mere noise in our current readings of Whitman might turn out to be sites of meaning and significance in future analyses of his life and work" (The Mickle Street Review no. 10 [1988], 114).

10. Brown, kraft-material notebook, $9.2 \times 14.9 \mathrm{~cm}$, containing forty, twenty-two ruled leaves. Leaves are attached through cover with string knotted inside. Evidence of tape along outside of cover at fold, now missing. Entries written with plain pencil unless noted. Front and back covers are blank with the exception of several ink stains on the outside. Reverse sides of leaves are blank unless noted. Measurements are approximate. 
11. Whitman is referring to the family farm of the Staffords where he spent much of his time from 1876 on. The farm was located one and a half miles from Glendale, N.J., which was twelve miles away from Camden. Whitman also called the farm Timber Creek, White Horse, and Kirkwood.

12. Harry Stafford was one of the most important young men in Whitman's life; see The Correspondence, edited by Edwin Haviland Miller (New York: New York University Press, 1961-1977), 3:2-7, for a discussion of Whitman's relationship with Harry; hereafter The Correspondence is abbreviated Corr.

13. Probably Harry's mother, Susan Stafford. Of Mrs. Stafford, Whitman wrote to her son: "There is not a nobler woman in Jersey" (Corr. 3:3).

14. Whitman would later send this acquaintance a copy of an article he was interested in that appeared in the Philadelphia Progress, April 30, 1881. He sent it to 1412 Walnut St., Philadelphia. (This name appears as "Allan" Leslie Belleville in DBN 2:222, 234).

15. Probably a note to remind himself to include Native-American references in a text he was working on.

16. This date, though clear, seems curiously out of place here, with the majority of entries having been made between 1876-1879.

17. A family singing group, a favorite of Whitman (PW 2:696, 697).

18. Unidentified.

19. Ringtown, Pennsylvania, was a favorite excursion spot for Whitman (NUPM 3:1187, 1188).

20. Reading Railroad news/ticket agent.

21. See $D B N 1: 84,178$; and $D B N 2: 302$.

22. Gaining back his strength and spirit at Timber Creek, Whitman reveled in the nature he rediscovered on the farm. Sitting for hours in the sun, he rendered his perceptions of and reactions to the surroundings. Sounds, birds, insects, all attracted his attention, but the trees impressed him the most. The listing in this notebook represents a partial catalogue of those companions with whom Whitman shared his days on Stafford farm. On May 14, 1881, an article appeared in the Philadelphia American, entitled "Bumble-Bees and Bird Music," which builds upon this list and its general structure (PW 1:123-126).

23. Whitman met Joshua Killingbeck in Camden and later hired him to pave the front walk of his Mickle Street house (DBN 2:335).

24. This notebook is the same type and size as the Gilchrist Notebook (see note 9). It is difficult to determine which cover is front and which is back. Reverse sides of leaves are blank unless noted. Measurements are approximate.

25. Mrs. Anne Gilchrist came to Philadelphia in 1876 with three of her children to be near Whitman. Although he had attempted to dissuade her from leaving England, her determination, as well as passion for the poet, remained unchecked. Her fantasy regarding the relationship that would ensue upon their meeting inevitably gave way as she painfully came to recognize that the poet did not share her affection and could not fulfill her fantasies. In the spring of 1878 , she left Philadelphia to be near her daughter who was studying medicine in Boston. This entry documents her arrival in Massachusetts. 
26. Possibly a trial of the title for Two Rivulets (Camden, New Jersey, 1876), which constituted the companion volume to the 1876 "Centennial Edition" of Leaves of Grass. Two Rivulets includes new poetry and prose, as well as Democratic Vistas, a group of "Centennial Songs-1876," As a Strong Bird on Pinions Free, Memoranda During the War, and Passage to India. In the preface to Two Rivulets, Whitman states that he put the book together "at the eleventh hour, under grave illness"(5).

27. Probably trial titles for journalism pieces Whitman was thinking of writing.

28. This person has not been completely identified, although it is known that Whitman had dinner with him along with Charles Peterson and John Johnston in November or December of 1878 . He is mentioned in $D B N$ as a "banjoist at Johnny Johnston's" (DBN 1:127, 129).

29. In October 1873, Whitman, in precarious health, moved in with his brother George and his sister-in-law Louisa at 431 Stevens Street, a new house on the corner where he chose a third-story bedroom facing south. He lived here for eleven years, until 1884 when he moved to Mickle Street where he would live until his death in 1892 .

30. Unidentified.

31. Whitman's “oculist” (Corr. 5:105).

32. Originally proposed by Whitman's New York literary friends, Whitman's first lecture on the death of Lincoln was scheduled for April 1878. Illness caused a postponement until Whitman's appearance at Steck Hall in Manhattan on April 14, 1879. He repeated the lecture almost annually through 1886 .

33. Apparently another title considered for Two Rivulets (see note 26).

34. Brown leather veneer cover over white cardboard notebook, $10.16 \mathrm{X} 16.83 \mathrm{~cm}$, partially disbound, containing sixty-five, twenty-two ruled leaves. Leaves are sewn in with string. Outside covers are blank. Reverse sides of leaves are blank unless noted. Measurements are approximate.

35. Unidentified.

36. Additional information concerning " $\mathrm{H}$. Cutler" has yet to be located.

37. Damon Y. Kilgore (1827-1888), Philadelphia lawyer and member of the Liberal League of Philadelphia. Kilgore arranged for Whitman to give a lecture on the $140^{\text {th }}$ anniversary of Thomas Paine's birthday at Lincoln Hall in Philadelphia on January 28, 1877. Whitman spent Thanksgiving with the Kilgore family in 1880 (Corr. 3:61, 75-76, 199).

\section{Unidentified.}

39. Unidentified.

40. This was Anne Gilchrist's son, Herbert, who looked at Whitman as ancle. Herbert was studying to become a painter, and he spent much of the fall of 1878 with Whitman, painting his portrait at Timber Creek, but rejoined his mother in November. (For commentary on Gilchrist's painting and its reproduction, see Gay Wilson Allen's "The Iconography of Walt Whitman," in Edwin Haviland Miller's The Artistic Legacy of Walt Whitman [New York: New York University Press, 1970], 137-140.) Whitman wrote an unsigned notice about the painting for a Camden paper ( $D B N$ $1: 60)$.

41. The picture was probably being framed at Payne's (see note 40 ). 
42. Unidentified.

43. A "First Violin - M. Smithers" appears in a listing of the Camden Parlor Orchestra in $D B N 1: 231$.

44. Unidentified.

45. See note 20 .

46. Unidentified.

47. Unidentified.

48. James Gibbons Huneker (1857-1921) was a U.S. critic of music, art and literature, a leading exponent of impressionistic criticism, as well as an author. He came to see Whitman and later published "A Visit to Walt Whitman" in his Ivory Apes and Peacocks (New York: Scribners, 1915), 22-31.

49. Called on Whitman on April 16, 1878. William M. F. Round remains unidentified except as a friend of Joaquin Miller and a journalist ( $D B N$ 1:95).

50. This is probably "Paddy" Connelly, whom Whitman describes as a "little blackeyed post boy at the ferry" in an 1891 notebook (see $D B N 1: 230$ ). He may also be one of the "young Connelly boys" who came to see Whitman at his home in September 1887 (DBN 2:435).

51. Unidentified.

52. The son of J.B. Lippincott of Lippincott's Magazine, one of Whitman's publishers through the 1870 s and 1880 s (DBN 1:148).

53. This is Anne Gilchrist's address after she left Philadelphia late in April 1878 (see note 25$)$.

54. Charles F. Bender was a hatter who operated in Philadelphia and who presented Whitman with one of his famous hats ( $D B N 1: 100)$.

55. Probably wife of John Bigelow, Minister to France, co-editor of the New York Evening Post from 1848 to 1861 , whom Whitman visited in West Point, New York, on June 16, 1878 (see Corr. 3:121).

56. Whitman wrote Erastus Brainerd on December 9, 1879, and sent him the poem, "What Best I See in Thee," published in the Philadelphia Press on December 17, 1879, and later included in the 1881-1882 edition of Leaves. Brainerd probably worked for the Press (DBN 1:97).

57. Unidentified.

58. Unidentified. 